\title{
COMPREHENSIVE ASSESSMENT OF ENDOTHELIUM-DEPENDENT MEDIATORS IN PATIENTS WITH ACUTE MYOCARDIAL INFARCTION AND DIABETES MELLITUS TYPE 2*
}

\author{
Zaikina T. S., Kravchun P. G., Minukhina D. V., \\ Minukhin D. V., Yevtushenko D. O., Kudrevych I. O. \\ Kharkiv National Medical University, Kharkiv, Ukraine; \\ Kharkiv Medical Academy of Postgraduate Education, Kharkiv, Ukraine \\ zaikina_tatyana@ukr.net
}

According to modern ideas about the mechanisms of acute myocardial infarction (AMI), the endothelium of the coronary artery is directly involved in the cascade of pathological changes [1].

Rupture of the atherosclerotic plaque is accompanied by a violation of the integrity of the endothelial monolayer. Metabolic disorders associated with type 2 diabetes mellitus (DM), such as hyperglycemia, insulin resistance, dyslipidemia, oxidative stress, only worsen a degree of endothelial injury [2,3]. This leads to the release into the general circulation of a number of biologically active substances endothelium-dependent mediators with wide range of effects.
One of the key functions of a healthy endothelium is the regulation of vascular tone, which is realized through the synthesis of nitric oxide (NO) from L-arginine under the influence of a special enzyme - endothelial nitric oxide-synthase (NOS) [4]. It was established that in AMI there is a decrease in the level of endothelial NOS, resulting in impaired endothelium-dependent dilatation of blood vessels [5].

Plasminogen activator inhibitor-1 (PAI-1) plays a crucial role in the pathogenesis of AMI preventing dissolution of thrombi. PAI-1 is secreted mainly by injured endothelial cells, it inhibits the dissolution of fibrin threads and promotes thrombosis [6]. In addition to the re-

* The work was carried out in accordance with the scientific theme of the Department of Internal medicine № 2 and clinical immunology and allergology named after academician L. T. Malaya "Profibrotic, immunoinflammatory factors and anemic syndrome as markers of prognosis in patients with chronic heart failure in coronary heart disease and type 2 diabetes within the cardiorenal continuum» (State registration number: 0114U003389) and «Ischemic heart disease under conditions of polymorbidity: pathogenetic aspects of development, course, diagnosis and improvement of treatment» (State registration number: 0118U000929)

Institution, which financed the research: the Ministry of Health of Ukraine.

The authors assume responsibility for the published work.

The authors guarantee absence of competing interests and their own financial interest when carrying out the research and writing the article.

The manuscript was received by the editorial staff 19.02.2021. 
gulation of fibrinolysis, PAI-1, participating in the reception of insulin, enhances the insulin resistance [7, 8].

Soluble cluster of differentiation 40 (sCD40), expressed on the surface of endothelial cells and platelets, takes part in the processes of activation of leukocyte-platelet interaction, resulting in initiation of intravascular inflammation, increased platelet aggregation and throm- bus formation [9]. It has been recently shown that circulating soluble CD40 ligand (sCD40L) is closely correlated with the severity of insulin resistance and dyslipidemia in diabetic patients [10].

The aim of study is to evaluate the levels of endothelium-dependent mediators - NOS, PAI-1 and circulating sCD40L in patients with AMI and concomitant type 2 DM.

\section{MATERIALS AND METHODS}

255 patients with AMI who underwent inpatient treatment at the myocardial infarction department of Kharkiv City Clinical Hospital № 27 were enrolled in the study. They were referred in 2 groups depending on the presence of concomitant type 2 DM: 1 group - 143 patients with concomitant type 2 DM; 2 group 112 patients without concomitant disturbances of carbohydrate metabolism.

AMI was diagnosed according to the criteria of the European Society of Cardiology, 2017 [11]. Type 2 DM was diagnosed according to the criteria of the American Diabetes Association (ADA), 2020 [12].

Blood samples were obtained on the $1^{\text {st }}$ and $10^{\text {th }}$ days of AMI under the basal conditions, NOS blood serum level was determined with commercial enzyme linked immunosorbent assay ELISA kit (Bender Medsystem, Austria), PAI-1 blood serum level was determined with commercial enzyme linked immunosorbent assay ELISA kit (Technoclone GmbH, Austria), sCD40L blood serum level was determined with commercial enzyme linked immunosorbent assay ELISA kit (YH Biosearch Laboratory, China), according to the manufacturer's instruction, and all these were performed with Automated EIA Analyzer «LabLine-90» (Austria). The data were processed statistically with IBM SPSS Statistics software: quantitative variables were described by the following parameters: median (Me), $25^{\text {th }}$ and $75^{\text {th }}$ percentiles $(\mathrm{Q} 1$; Q3), the Mann-Whitney U-test was used for the assessment of the differences between two independent samples, $\mathrm{p}$-statistical significance ( $p<0,05$ is considered statistically significant).

Before the study, patients were informed about the essence of the study, its purpose and possible results. All participants signed up the informed agreement. This study was approved by the local ethics committee in accordance to the recommendations of the ethical committees for biomedical research, Ukrainian legislation for health protection, the $7^{\text {th }}$ Revised Helsinki Declaration for medical research involving human subjects [13].

\section{RESULTS AND DISCUSSION}

Analyzing the levels of NOS on the first day of AMI (table 1), we found that in the group of patients with concomitant type $2 \mathrm{DM}$ the median endothelial NOS was $2,6 \mathrm{ng} / \mathrm{ml}$, while in the group of patients without concomitant car- bohydrate metabolism disorders $-4,2 \mathrm{ng} / \mathrm{ml}$ $(\mathrm{p}<0,01)$, that indicates much more significant violation of vasodilatory function of the endothelium in the cohort of patients with type 2 DM. Over the next 10 days, NOS levels un-

Levels of NOS measured on the $1^{\text {st }}$ and $10^{\text {th }}$ days, in patients

Table 1 with AMI depending on the presence of concomitant type 2 DM, (Me [Q1; Q3])

\begin{tabular}{c|c|c|c}
\hline Parameter & $\begin{array}{c}\text { Patients with AMI + DM } \\
(\mathbf{n}=\mathbf{7 3})\end{array}$ & $\begin{array}{c}\text { Patients with AMI } \\
(\mathbf{n}=\mathbf{5 7})\end{array}$ & $\mathbf{p}$ \\
\hline NOS, ng/ml, $1^{\text {st }}$ day & $2,6[2,21 ; 4,15]$ & $4,2[3,6 ; 4,8]$ & $<0,01$ \\
\hline NOS, ng/ml, $1^{\text {th }}$ day & $4,4[3,85 ; 5,5]$ & $5,63[5,63 ; 13,96]$ & $<0,01$ \\
\hline
\end{tabular}

Note:

$\mathrm{p}<0,05$ is statistically significant. 
der the influence of the treatment, indicating a gradual restoration of endothelial protective properties. However, the median NOS in the cohort of AMI patients with type $2 \mathrm{DM}$ remained lower than in the cohort of AMI patients without concomitant carbohydrate metabolism disorders $-4,4 \mathrm{ng} / \mathrm{ml}$ and $5,63 \mathrm{ng} / \mathrm{ml}$ respectively $(\mathrm{p}<0,01)$.

When assessing PAI-1 levels (table 2), significantly higher median PAI-1 was found in patients with AMI with concomitant type $2 \mathrm{DM}$ compared with patients with AMI without carbohydrate metabolism disorders $(68,85 \mathrm{ng} / \mathrm{ml}$ and $53,1 \mathrm{ng} / \mathrm{ml}$ respectively, $\mathrm{p}<0,01)$, which indicated a more pronounced inhibition of fibrinolysis in a cohort of patients with concomitant disorders of carbohydrate metabolism, due, apparently, to the presence of diabetes-induced endothelial dysfunction. A similar negative trend occurred in the re-determination of PAI-1 levels on the 10th day of AMI $-63,24 \mathrm{ng} / \mathrm{ml}$ and $42,2 \mathrm{ng} / \mathrm{ml}$ respectively $(\mathrm{p}<0,01)$.

Analyzing the levels of the marker of intravascular inflammation $\mathrm{SCD} 40 \mathrm{~L}$ in patients with acute coronary artery occlusion (table 3), we found that in the group of patients with type $2 \mathrm{DM}$ sCD40L was also significantly higher than in the comparison group $-3,78 \mathrm{ng} / \mathrm{ml}$ and $3,35 \mathrm{ng} / \mathrm{ml}$ respectively $(\mathrm{p}<0,01)$. A similar pattern was observed on the 10th day of illness, amounting to $3,07 \mathrm{ng} / \mathrm{ml}$ and $2,45 \mathrm{ng} / \mathrm{ml}$ respectively $(p<0,01)$, which indicates a significantly greater severity of the inflammatory reaction in the endothelial monolayer vascular wall in conditions of concomitant diabetes.

Our analysis of endothelium-dependent mediators showed a statistically significant reduction of endothelial NOS, increase in PAI-1 and sCD40L levels in patients with AMI and concomitant type $2 \mathrm{DM}$ compared with patients without carbohydrate metabolism disorders. The results of our study are closely correlated with the results of other scientific works, dedicated to the estimation of these endotheliumdependent mediators.

Thus, Huang Y. and co-authors also found a significant increase in $\mathrm{sCD} 40 \mathrm{~L}$ levels in patients with AMI and type 2 DM. Moreover, the prognostic value of this indicator in the diagnosis of painless forms of AMI in diabetics was demonstrated [14]. Seijkens T. and co-authors also emphasized the presence of predictor properties of SCD40L in relation to the development of major cardiovascular events in patients with type 2 DM [15].

Along with sCD40L elevation some researchers also detected increased levels of PAI-1 in diabetic patients with AMI, that remained elevated in the dynamics of treatment [16]. Taking into account its prognostic value as a marker for major adverse cardiovascular events especially in diabetic patients [17], it

Levels of PAI-1 measured on the $1^{\text {st }}$ and $10^{\text {th }}$ days, in patients

Table 2 with AMI depending on the presence of concomitant type 2 DM, (Me [Q1; Q3])

\begin{tabular}{c|c|c|c}
\hline Parameter & $\begin{array}{c}\text { Patients with AMI + DM } \\
(\mathbf{n}=\mathbf{7 3})\end{array}$ & $\begin{array}{c}\text { Patients with AMI } \\
(\mathbf{n}=\mathbf{5 7})\end{array}$ & $\mathbf{p}$ \\
\hline PAI-1, ng/ml, $1^{\text {st }}$ day & $68,85[60,95 ; 71,1]$ & $53,1[43,38 ; 59,6]$ & $<0,01$ \\
\hline PAI-1, ng/ml, $1^{\text {th }}$ day & $63,24[59,41 ; 69,88]$ & $42,4[38,7 ; 48,9]$ & $<0,01$ \\
\hline
\end{tabular}

Note:

$\mathrm{p}<0,05$ is statistically significant.

Levels of SCD40L measured on the $1^{\text {st }}$ and $10^{\text {th }}$ days in patients Table 3 with AMI depending on the presence of concomitant type 2 DM, (Me [Q1; Q3])

\begin{tabular}{c|c|c|c}
\hline Parameter & $\begin{array}{c}\text { Patients with AMI + DM } \\
(\mathbf{n}=\mathbf{7 0})\end{array}$ & $\begin{array}{c}\text { Patients with AMI } \\
(\mathbf{n}=\mathbf{5 5})\end{array}$ & $\mathbf{p}$ \\
\hline${ }_{\mathrm{sCD} 40 \mathrm{~L}, \mathrm{ng} / \mathrm{ml}, 1^{\text {st }} \text { day }}$ & $3,78[3,67 ; 3,9]$ & $3,35[2,88 ; 3,63]$ & $<0,01$ \\
\hline sCD40L, ng/ml, $1^{\text {th }}$ day & $3,07[2,88 ; 3,35]$ & $2,45[2,12 ; 2,81]$ & $<0,01$ \\
\hline
\end{tabular}

Note:

$\mathrm{p}<0,05$ is statistically significant. 
should be recommended to measure it in a routine practice in order to prevent such unfavorable complications.

Our results related to NOS levels in diabetic patients with acute coronary occlusion were supported in the scientific research of Minukhina D. and co-authors, which showed considerable reduction of NOS levels in patients with AMI and concomitant type 2 DM. Performing of percutaneous coronary intervention did not contribute to the statistically significant increasing of NOS [18] compared to non-invasive therapy in diabetic patients. This trend is apparently due to the additional negative impact of metabolic disorders associated with type $2 \mathrm{DM}$ on the endothelium of the coronary arteries, accompanied by increased release of sCD40L and PAI-1, which cause the development of intravascular inflammation in the arterial wall, inhibition of fibrinolysis of the formed thrombus, as well as reducing the synthesis of endothelial NOS, which is responsible for the regulation of vascular tone.

\section{CONCLUSION}

1. Taking all the arguments, mentioned above, into account, we can conclude that presence of type 2 diabetes mellitus contributes to the worsening of the endothelial function, assessed by the levels of endothelial NOS, PAI-1, sCD40L in patients with acute myocardial infarction compared to non-diabetic patients.
2. Despite performed treatment, this tendency remains unchanged even up to $10^{\text {th }}$ day after acute atherothrombosis. This partially defines poor prognosis due to the maintenance of intravascular inflammation, delay in thrombus dissolution and impaired vascular dilation.

\section{REFERENCES}

1. Berns SA, Shmidt EA, Yuhno ES, et al. Kardiologiya 2015; 4: 14-18. doi: 10.18087/cardio.

2. Sena CM, Pereira AM, Seica R. Biochim Biophys Acta 2013; 1832: 2216-2231. doi:10.1016/j.badis.2013.08.006.

3. Ketete M, Cherqaoui R, Maqbool A, et al. J Biomed Sci Engineering 2013;6: 593-597. doi:10.4236/jbise.2013. 66075.

4. Fleming I, Busse R. Cardiovasc Res 1999; 43(3): 532 541. doi: 10.1016/s0008-6363(99)00094-2.

5. Li J-L, Yang Z, Wu S, et al. J Int Med Res 2012; 40(2): 687-693. doi: 10.1177/147323001204000232.

6. Sobel B, Taatjes D, Schneider D. Arterioscler Thromb Vasc Biol 2003; 23(11): 1979-1989. doi:10.1161/01.atv. $0000091250.53231 .4 \mathrm{~d}$.

7. Lopez-Alemany R, Redondo J, Nagamine Y, et al. Eur J Biochem 2003; 270(5): 814-821. doi: 10.1046/j.14321033.2003.03453.x.

8. Juhan-Vague I, Alessi M, Vague P. Diabetologia 1991; 34(7): 457-462. doi: 10.1007/bf00403280.

9. Aloui C, Priqent A, Sut C. Int J Mol Sci 2014; 15(12): 22342-22364. doi:10.3390/ijms151222342.
10. Zaikina TS. Visnyk problem biolohii i medytsyny 2015; 3(2): 118-122. doi:10.29254.

11. Ibanez B, James S, et al. Eur Heart J 2017: 1-66. doi:10.1093/eurheartj/ehx393

12. American Diabetes Association. Diabetes Care 2000; 43(1): 14-31. doi: 10.2337/dc20-S002.

13. World Medical Association. World Medical Association Declaration of Helsinki: ethical principles for medical research involving human subjects. JAMA 2013; 310(20): 2191-2194. doi: 10.1001/jama.2013.281053.

14. Huang Y, Qiu J, Zhang D, et al. Biofactors 2011; 37(2): 88-94. doi: 10.1002/biof.145.

15. Seijkens T, Kusters P, Engel D, et al. Diab Vasc Dis Res 2013; 10(2): 115-122. doi:10.1177/1479164112455817.

16. Gruzdeva O, Uchasova E, Dyleva Y, et al. Diab Metab Syndr Obes 2013; 6: 293-301. doi: 10.2147/DMSO.S46627.

17. Jung R, Motazedian P, Ramirez F, et al. Thromb $J$ 2018; 16: 12. doi: 10.1186/s12959-018-0166-4.

18. Minukhina DV, Babadjan VD, Minukhin DV, et al. Wiad Lek 2020; 73(1): 123-127. doi: 10.36740/WLek202001124. 


\title{
COMPREHENSIVE ASSESSMENT OF ENDOTHELIUM-DEPENDENT MEDIATORS IN PATIENTS WITH ACUTE MYOCARDIAL INFARCTION AND DIABETES MELLITUS TYPE 2
}

\author{
Zaikina T. S., Kravchun P. G., Minukhina D. V., Minukhin D. V., \\ Yevtushenko D. O., Kudrevych I. O. \\ Kharkiv National Medical University, Kharkiv, Ukraine; \\ Kharkiv Medical Academy of Postgraduate Education, Kharkiv, Ukraine \\ zaikina_tatyana@ukr.net
}

The aim of study is to evaluate the levels of endothelium-dependent mediators: endothelial nitric-oxide synthase (NOS), plasminogen activator inhibitor-1 (PAI-1) and circulating soluble CD40 ligand (sCD40L) in patients with acute myocardial infarction (AMI) and concomitant type 2 diabetes mellitus (DM). The study included 255 patients with AMI, who were divided into two groups depending on the presence of concomitant type 2 DM: 1 group - 143 patients with concomitant type 2 DM; 2 group - 112 patients without concomitant disturbances of carbohydrate metabolism. Studied endothelial-dependent indicators were investigated using enzyme-linked immunosorbent assay. Statistical data were processed using the Mann-Whitney U-test, quantitative variables were described by the following parameters: median (Me), $25^{\text {th }}$ and $75^{\text {th }}$ percentiles (Q1; Q3). Analyzing the studied indicators on admission of patients to the hospital, a statistically significant decrease in NOS levels $(p<0,01)$, as well as an increase in PAI-1 $(p<0,01)$ and sCD40L $(p<0,01)$ in the cohort of patients with AMI and concomitant type 2 DM compared with patients without disturbances of carbohydrate metabolism. This indicates a more significant violation of endothelium-dependent vasodilation, thrombin fibrinolysis and activation of intravascular inflammation caused by comorbidity. Over the next 10 days, an increase in NOS levels, a decrease in PAI-1 and sCD40L levels were observed in patients of both groups, indicating a gradual improvement of the endothelial function. However, in patients with AMI and concomitant type 2 DM, the levels of the studied endothelium-dependent mediators continued to differ statistically even on the 10th day after acute occlusion of the coronary artery. In our opinion, this tendency is caused by the negative impact of metabolic disorders associated with type $2 \mathrm{DM}$ on the endothelium of the coronary arteries in patients with insulin resistance and, apparently, may increase the risk of complications of AMI.

Key words: acute myocardial infarction, diabetes mellitus type 2, NOS, PAI-1, sCD40L.

\section{КОМПЛЕКСНА ОЦІНКА ЕНДОТЕЛІЙ-ЗАЛЕЖНИХ МЕДІАТОРІВ У ХВОРИХ З ГОСТРИМ ІНФАРКТОМ МІОКАРДА ТА ЦУКРОВИМ ДІАБЕТОМ 2 ТИПУ}

Заїкіна Т. С., Кравчун П. Г., Мінухіна Д. В., Мінухін Д. В., Свтушенко Д. О., Кудревич I. О.

\author{
Харківський національний медичний університет, м. Харків, Украйна; \\ Харківська медична академія післядиплолной освіти, л. Харків, Украӥна \\ zaikina_tatyana@ukr.net
}

Мета дослідження - оцінити рівні ендотелій-залежних медіаторів, а саме ендотеліальної синтази оксиду азоту (NOS), інгібітору активатора плазміногену-1 (PAI-1) і циркулюючого розчинного ліганду CD40 (sCD40L) у пацієнтів з гострим інфарктом міокарда (ГIM) і супутнім цукровим діабетом 2-го типу (ЦД). У дослідження були включені 255 пацієнтів з ГІМ, які були розділені на дві групи в залежності від наявності супутнього ЦД 2-го типу: 1 група - 143 паціента з супутнім ЦД 2-го типу; 2 група - 112 пацієнтів без порушень вуглеводного обміну. Досліджувані показники визначали імуноферментним методом. Статистичні дані обробляли за допомогою U-критерію Манна - Уітні, кількісні змінні описувались такими параметрами: медіана (Me), 25-й та 75-й процентилі (Q1; Q3). Аналізуючи досліджувані показники при надходженні пацієнтів до стаціонару, було встановлено статистично значуще зниження рівня NOS ( $<<0,01)$, а також підвищення рівнів PAI-1 ( $<<0,01)$ та sCD40L $(\mathrm{p}<0,01)$ у когорті хворих з ГІМ та супутнім ЦД 2-го типу порівняно з хворими без інсулінорезистентності. Це свідчить про наявність більш значного порушення ендотелій-залежної вазодилятації, процесів фібринолізу тромбу та активації внутрішньосудинного запалення, спричинених коморбідністю. Впродовж наступних 10 днів було виявлено збільшення рівнів NOS, зниження рівнів PAI-1 та SCD40L у паціентів обох досліджуваних груп, що свідчить про поступове покращення стану ендотелію. Утім, не дивлячись на це, у пацієнтів на ГІМ та супутнім ЦД 2-го типу, рівні досліджуваних ендотелій-залежних медіаторів продовжували статистично відрізнятися від рівнів NOS, PAI-1, sCD40L у пацієнтів без порушень вуглеводного обміну навіть на 10-й день після гострої оклюзії вінцевої артерії. На нашу думку, подібна картина пов'язана з негативним впливом метаболічних порушень, асоційованих з ЦД 2-го типу на ендотелій коронарних артерій, який зберігається у пацієнтів з інсулінорезистентністю та, вочевидь, може зумовлювати підвищений ризик розвитку ускладнень гострого періоду інфаркту міокарда.

К л юч о в і сл о в а : гострий інфаркт міокарда, цукровий діабет 2-го типу, sCD40L, PAI-1, NOS. 